Volume 3

Number 4 JAAER Summer 1993

Article 8

Summer 1993

\title{
Is Aerospace Education Outdated?
}

Raymond J.Johnson

Follow this and additional works at: https://commons.erau.edu/jaaer

\section{Scholarly Commons Citation}

Johnson, R. J. (1993). Is Aerospace Education Outdated?. Journal of Aviation/Aerospace Education \& Research, 3(4). https://doi.org/ 10.15394/jaaer.1993.1105

This Article is brought to you for free and open access by the Journals at Scholarly Commons. It has been accepted for inclusion in Journal of Aviation/ Aerospace Education \& Research by an authorized administrator of Scholarly Commons. For more information, please contact commons@erau.edu. 


\title{
IS AEROSPACE EDUCATION OUTDATED?
}

\author{
Raymond J. Johnson
}

In considering a topic for the "Issues in Education" Panel at the 1993 National Congress for Aviation and Space Education, it appeared logical to consider a basic question: Is the current aerospace education effort outdated at this time? A quick response is no....but this demise could happen if we fail to adjust to the rapid changes that are taking place throughout our society and subsequently in our schools. The shifting school environment and the emerging generation of adolescents require new considerations in developing materials and activities for aviation/space education. About two years ago an awareness of the gradual decline of young people joining aviation organizations or otherwise becoming involved with their activities was a priority concern of the 39 member organization Illinois Aviation Forum.

\section{THE ILLINOIS AVIATION FORUM}

A research project was undertaken to address this concern focusing on the 10-17 year age group. The design was to provide the organizational planners with a description of the attitudes, interests, and values of the emerging generation. A computer search of papers published on adolescent behavior was combined with the output of an invitational working seminar with recognized leaders from the major youth programs. Also, a related survey of aviation and aerospace education organizations was undertaken to determine the content and the delivery systems used for their programs. The full report of this project is available from the Federal Aviation Administration's (FAA) Education Office.

\section{Values and Attitudes Examined}

Some pertinent observations from the study indicated several specific factors that should influence the planning process in developing materials and activities. There are strong indications that traditional values, generational attitudes, and motivations are being challenged. Again, it must be stressed that the purpose of the study was to provide insight, leaving the determination to the reader as to whether the changes reported are positive or negative.

Some of the significant societal trends identified were:

$\diamond$ The rapid shift to an electronic lifestyle is obvious with children becoming accustomed to receiving information visually and orally. This is affecting reading skills. $\diamond$ The traditional two parent family is declining as the norm.

$\diamond$ Parents are having a more difficult time guiding their children, who are subject to considerable stresses in regard to drug abuse, sex, academic achievement, and for many young people a concern as to their future economic wellbeing.

$\diamond \quad$ Liability factors are decreasing the number of adult volunteers available to participate in youth activities, and the nature of their involvement is changing.

$\diamond$ The media coverage of aviation tends to have a negative tone which has influenced both the public's and young people's perception of aviation activities.

The study also identified significant trends within today's adolescent culture which merit examination:

$\diamond$ Teens have considerable sensitivity about social and environmental issues.

$\diamond$ Teens are subject to peer influence and frequently it becomes more important for them to be part of a group than to pursue their personal interests.

$\diamond$ Electronic simulation games can become a source of realistic action for many young people. The "Top Gun" type of promotion has produced a very macho perception of piloting. A recent article noted that: 
basic flight training pales in comparison to the multi-media, high-tech diversions available to most youth. Today a twelve-year old with a PC can shoot an ILS approach in a 747 cockpit. . .and even this is tame when compared with the simulations of flying mock combat with Chuck Yeager in a F17 aircraft. (Illinois Department of Transportation, 1992, p. 10.)

Even a source for more realistic combat scenarios has been announced as ready for the arcade market. This utilizes a moving simulator with multi-operator capability.

$\diamond$ As increased options become available, there is a tendency for teens to drop an activity if quick gratification is not realized. Emerging as a common characteristic is the shrinking attention span coupled with a desire to be entertained rather than mentally challenged.

$\diamond$ There is considerable skepticism developing among young people concerning most adult institutions. They want explanations which are logical to them before accepting the necessity of specific rules. Likewise, tradition has a more limited meaning for this generation.

\section{OTHER EDUCATIONAL CHANGES}

The field of education is also experiencing significant challenges which may influence the continuance of existing aviation/space activities in the classrooms or the implementation of new activities. Financial constraints are generally increasing with the spreading demand for academic accountability, often accompanied by state mandated goals for learning. The added consideration of societal changes including mounting discipline and liability problems all add to escalating pressures in the classroom environment.

There is, however, strong evidence at this Congress that aviation and space education continues to be as exciting, as challenging, and from our standpoint as vital as ever. It is obvious that there will be an on-going requirement for a critical review of the content, of the packaging, of the marketing, and of the delivery systems being used.

Computers and new technology are rapidly becoming commonplace in schools, even at the very lowest grade levels. CD-ROM is leading to interactive learning techniques. Linked computers and access to established networks are also part of the change in the education process. Group simulation, long-term team problem solving projects with competitions, and remote interfacing with guest experts are also adding exciting new dimensions to learning.

It would appear that these developments are ahead of the presently available aviation/space education programs and materials. There is now progress underway to reshape the effort to attract a greater involvement of young people and teachers. For example, the FAA is establishing a readily accessible aviation education data base on the FEDIX computer network. Also, NASA and National Air and Space Museum are making computerbased information available.

\section{THE COALITION FILLS A GAP}

Another major development which has a considerable potential for a more effective introduction of aviation education to the education community is the formation of the National Coalition for Aviation Education.

It appears that in most states there are some 40 or 50 different organizations independently offering aerospace education materials, resources, assistance, and opportunities to teachers and to young people. This is a great effort except for the fragmentation and duplication that exists. Somewhat disconcerting is the limited followthrough support that appears to be available.

The Coalition initially represents 14 of these organizations, including the FAA. It has the opportunity to develop a common focus and a marketing plan that will produce far better results than each can produce separately. It is conceivable that through pooling resources and through the development of advanced offerings such as CD-ROM, many programs would become available to schools and young people.

Perhaps equally important, this coalition is in an excellent position to establish a working interface with the education associations on the national level. There was a time when one of the leading proponents of aviation education was a committee of the American 
Association of School Administrators. Superintendents talking to superintendents on this subject brought action. EXPERIMENTAL AIRCRAFT ASSOCIATION INITIATIVES

A more direct approach to involve a large number of young people in aviation education is the recent Experimental Aircraft Association's (EAA) creation of the "Young Eagle" program. The stated goal is to provide one million young people with motivational flight experience during the next ten years, utilizing volunteer pilot members around the country. The young participants will be encouraged to join one of the existing national aviation youth organizations or to participate in some other aviation activity.

The Young Eagle program has already produced a secondary value of becoming a major stimulus for other aviation groups to join what could become a "bandwagon" in this phase of aviation education. This is also an opportunity to reverse the frequent image of airports as being "unfriendly" to kids.

In reality only a very small number of the young people touched by this nation's aviation/space education programs will become pilots, aircraft owners, or even be employed in the aerospace field. But significantly all can become informed voting citizens with many moving into positions of community influence. This role also has important implications for the future of aviation and space activities.

Again, returning to the initial question "Is the aerospace education effort outdated?" support can be given to both a positive view and a timely call for the aerospace education leadership to consider a "vision of the future" style of conference to focus upon how the apparent trends in society, in technology, and in education can be addressed for the advancement of aviation/space education. $\square$

Raymond J. Johnson, a University of Minnesota graduate in Business Administration and Industrial Engineering, earned a Masters Degree in Education from the National-Louis University. The recipient of many honors and awards, one of which was induction into the Illinois Aviation Hall of Fame and the National Hall of Honor for Distinguished Aerospace Educators, Mr. Johnson is retired as Chief, Office of Civil Air Patrol Affairs and Aviation Education for the Division of Aeronautics of the Illinois Department of Transportation. He is currently a delegate to the Federation Aeronautique Internationale (FAI) General Conference and is Vice President of its Education Commission.

\section{REFERENCE}

Illinois Department of Transportation. (1992, Sep-Oct) Division of Aeronautics. Civil air patrol activity report. Chicago. 